Kazimierz PAWŁOWSKI*

\title{
BAŚŃ O EROSIE I PSYCHE APULEJUSZA Z MADAURY Duchowe aspekty baśni
}

Apulejusz z Madaury, zwany Platończykiem, w świadomości kulturowej funkcjonuje głównie jako autor Metamorfoz, dzieła, w którym zapisał baśń O Erosie i Psyche, oraz nieco mniej znanej Apologii ${ }^{1}$. Apulejusz pozostawił po sobie także zbiór popisowych mów na różne tematy pod tytułem Florida oraz pisma filozoficzne'2.

Apulejusz z Madaury był bez wątpienia umysłem dużego formatu, przede wszystkim pisarzem, ale również filozofem, jednym z ważniejszych przedstawicieli średniego platonizmu, propagującego filozofię Platona. Z jego Apologii wiemy, że był pozbawiony zmysłu praktycznego i ścisłych, przyrodniczych zainteresowań, i nie stronił też, jak się wydaje, od magii. W tym momencie interesujące są przede wszystkim jego zainteresowania filozoficzne. Celem niniejszej pracy nie jest szersze omawianie filozofii Apulejusza ${ }^{3}$. Wypada jednak

" Prof. dr hab. Kazimierz Pawłowski - Kierownik Katedry Filozofii i Kultury Antycznej w Instytucie Filologii Klasycznej i Kulturoznawstwa na Wydziale Nauk Humanistycznych Uniwersytetu Kard. Stefana Wyszyńskiego w Warszawie; e-mail: k.pawlowski@uksw.edu.pl.

${ }^{1}$ Polskie przekłady tych dzieł: Apulejusz, Metamorfozy albo złoty osiot, thum. E. Jędrkiewicz, Warszawa 1976; Apulejusz, Apologia, czyli w obronie własnej księga o magii, thum. J. Sękowski, Warszawa 1975.

${ }^{2}$ Polskie przekłady pism filozoficznych Apulejusza: Apulejusz z Madaury, O bogu Sokratesa i inne pisma, tłum. K. Pawłowski, Warszawa 2002.

${ }^{3} \mathrm{Na}$ temat Apulejusza i jego filozofii zob. G. Barra, Il valore e significato del „, De deo Socratis” di Apuleio, „Annali della Facolta di lettere e Filosofia dell' Universita di Napoli” 9 (1960-1961) 67-119; tenże, La biografia di Platone nel „De Platone et eius dogmate” di Apuleio, „Rendiconti dell'Accademia di Architectura, Lettere e Belle Arti di Napoli” 38 (1963) 5-18; tenże, La questione dell'autencita del „De Platone et eius dogmate” e „De mundo” di Apuleio, „Rendiconti dell' Accademia di Archeologia, Lettere e Belle Arti di Napoli” 40 (1966) 127-188; tenże, Initia rerum. Un passo controverso del „De Platone et eius dogmate” di Apuleio, „Rendiconti dell' Accademia di Archeologia, Lettere e belle Arti di Napoli” 41 (1967) 35-42; tenże, Apuleio e il problema del male, „Vichiana” N.S. 1 (1972) 102-113; F. Berthold, Die religiösen Anschauungen des Apuleius, Bonn 1925; A. Bertozzi, La posizione filosofica di Apuleio, „Sophia” 17 (1949) 238-245; U. Carratello, Apuleio mori nel 163-164, „Giornale Italiano di Filologia” 16 (1963) 97-110; L. Chodaczek, Apuleianum, „Eos” 25 (1922) 56-58; tenże, Ad Apuleium, „Eos” 28 (1925) 56-58; E.H. Haight, Apuleius and his influence, New York 1927; J. Dillon, The Middle Platonists, 80 B.C. to A.D. 220, Ithaca New York 1977, London² 1996; M. Kawczyński, Życie Apulejusza Platończyka z Madaury, Kraków 
pokazać jej duchowe aspekty (dla filozofii średniego platonizmu właśnie te duchowe aspekty były bardzo ważne), by w tej perspektywie umieścić i zrozumieć samą baśń $O$ Erosie i Psyche. Przede wszystkim trzeba powiedzieć, że szczególna wrażliwość na duchowe aspekty ludzkiej egzystencji jest charakterystycznym znamieniem filozofii Apulejusza. Widać to niemal we wszystkich jego dziełach filozoficznych. Można wręcz powiedzieć, że w wymiarze duchowym filozofia Apulejusza przyjmuje wręcz postać misteriozofii ${ }^{4}$, pozostając ciągle na gruncie platonizmu. I to też jest charakterystyczną cechą filozofii i umysłowości Apulejusza. W swojej Apologii Apulejusz z dumą mówi o sobie jako o członku „,rodziny platońskiej”, podkreślając swoje silne związki z Platonem ${ }^{6}$. Filozofia Platona jest dla niego najwyższym osiagnięciem ludzkiego intelektu i ludzkiego ducha. Jest dlań wręcz objawieniem ,prawd boskich" . Kształtuje nie tylko jego świadomość i przekonania, lecz również jego duchowość. W sensie duchowym, filozofia Platona przejęła u niego rolę, którą w życiu wyznawców różnych religii pełnią oczyszczenia i wtajemniczenia rytualne. Sam Platon taki obraz filozofii maluje m.in. w Fedonie, który

1899; tenże, O pismach filozoficznych Apulejusza Platończyka z Madaury, Kraków 1900; H. Kleist, De L. Apulei Madaurensis libro qui inscribitur de philosophia morali, Göttingen 1874; C. Moreschini, La posizione di Apuleio e della scuola di Gaio nell'ambito del medioplatonismo, „Annali della Scuola Normale Superiore di Pisa” 33 (1964) 17-56; tenże, La demonologia medioplatonica e le Metamorfosi di Apuleio, „Maia” 17 (1956) 30-46; tenże, Studi sul „De dogmate Platonis” di Apuleio, Pisa 1966; tenże, Apuleio e il platonismo, Firenze 1978; K. Pawłowski, Filozoficzna sylwetka Apulejusza z Madaury, „Meander” 7-12 (1989) 339-352; tenże, Platoński ideat mędrca w „De Platone et eius dogmate” Apulejusza z Madaury. Doktryna „Homoiosis theo”, PrzRel 37 (1993) nr 3 (169), 3-11; tenże, Misteryjne i apollińskie watki w „De Platone et eius dogmate” Apulejusza z Madaury, PrzRel 37 (1993) nr 1 (167), 3-14. T. Sinko, De Apulei et Albini adumbratione, Cracoviae 1905; tenże, De vita Platonis Apuleiana, „Eos” 30 (1927) 101-112; tenże, Apuleiana, „Eos” 18 (1912) 137-167; M.W. Sullivan, Apuleian Logic. The Nature, Sources, and Influence of Apuleius's Peri Hermeneias, Amsterdam 1967; R.E. Witt, Albinus and the History of Middle Platonism, Cambridge 1937, Amsterdam 1971²; C. Zintzen, Der Mittelplatonismus, Darmastadt 1981.

${ }^{4}$ Por. G. Barra - U. Pannuti, Esperienza filosofica e religiosa di Apuleio, „Annali della Facolta di lettere e Filosofia dell' Universita di Napoli” 10 (1962-1963) 81-141, spec. 83. Barra i Pannuti podkreślają rolę magii, a także doświadczeń misteryjnych i mistycznych Apulejusza w jego życiu i filozofii. Zob. T. Mantenero, Enciclopedismo e misteriosofia in Apuleio, „Quaderni del Teatro Stabile di Torino" 20 (1970) 63-111. Wątki misteriozoficzne w filozofii Apulejusza akcentuje również Mantenero, zauważając, że w umysłowości Apulejusza nastąiła swego rodzaju fuzja filozofii z magią i religią. Por. Pawłowski, Misteryjne i apollińskie watki, s. 3-14.

${ }^{5}$ Por. Pawłowski, Filozoficzna sylwetka Apulejusza z Madaury, s. 339-352.

${ }^{6}$ Por. Appuleius, Apologia 64, 39.

${ }^{7} \mathrm{~W}$ owych czasach nie było to niczym nowym. Przypomnijmy znany topos, popularny zwłaszcza w środowisku średnich platoników, zgodnie z którym filozofia była czymś w rodzaju wyroczni i boskiego objawienia, ale skierowanego nie do prostych ludzi, którzy mieli swoje wyrocznie religijne, a do ludzi wykształconych, którym boskie prawdy, w stosownym dla siebie języku, obwieszczali filozofowie. Ów topos zastąpił stare porównywanie filozofii do poezji, w którym również chodziło nie o przekazywane treści, lecz o sposób ich przekazu (filozoficzny, a więc racjonalny, albo poetycki, czyli alegoryczny). 
był jednym z dwóch dialogów Platona, przetłumaczonych przez Apulejusza. Nazywa tu filozofię największa służbą Muzom i Apollinowi oraz oczyszczeniem i przygotowaniem do śmierci ${ }^{8}$. Podobne określenia znajdują się również u filozofa $\mathrm{z}$ Madaury ${ }^{9}$. Biorąc pod uwagę misteryjne pasje Apulejusza, który $\mathrm{z}$ upodobaniem wtajemniczał się w różne misteria, można się spodziewać, że studia nad filozofią Platona stanowiły w jego życiu, pod względem duchowym, coś analogicznego do wtajemniczeń misteryjnych, których wcześniej dostąpił. Stanowily coś w rodzaju duchowego przygotowania do „misterium śmierci”, czyli do ostatecznych wtajemniczeń wiodących do pełnego zjednoczenia z boskością, i zarazem do ostatecznego uwolnienia i oczyszczenia duszy z wszelkich śladów zmysłowego i cielesnego żywota. Analogie z misteriami zdają się tu same narzucać ${ }^{10}$. W misteriach oczyszczenie dokonuje się poprzez wtajemniczenia uruchamiane i pobudzane wprawdzie poprzez jakieś obrzędy i rytuały, które w jakiś sposób wyczulają wtajemniczanych na określone tajemnice, których mają dostapić, ale ich istotą jest zawsze egzystencjalne (a więc dogłębnie przeżywane) doświadczanie boskości ${ }^{11}$. Same rytuały i obrzędy, i wywołana przez nie specyficzna duchowa atmosfera, stanowią tu tylko czynnik pobudzający, niejako katalizujący autentyczne, duchowe przeżycia związane

\footnotetext{
${ }^{8}$ Por. Plato, Phaedo 61A; 64A-B; 67C-D; 76C-E; 69B-C; 82D - 83B.

${ }^{9}$ Por. Apuleius, De dogmate Platonis II 21, 250-251.

${ }^{10}$ Platon często powołuje się na święcenia i wtajemniczenia: Phaedo 69C-D; 81A-B; 62B
} (tu mowa o nauce tajemnej, pewnie orfickiej; por. Cratylus 400C); Gorgias 493B; 497C; Phaedrus 249C-D; 250C-E; 253C; Symposium 215 C. O religijnych aspektach filozofii Platona pisało wielu badaczy. P. Natorp (Platos Ideenlehre, Hamburg 1961, 508-509) pisze, że filozofia Platona przepojona jest religią i stanowi z nią jedną całość. Również K. Albert (Griechische Religion und Platonische Philosophie, Hamburg 1980, 68 i inne) sądzi, że filozofia Platona ma charakter wybitnie religijny, a nawet kultowy. Twierdzi wręcz, że filozofia Platona jest kontynuacją greckiej religii i służy nawiązaniu przerwanej więzi z Bogiem (tamże, s. 121). K. Albert akcentuje też misteryjne, zwłaszcza orfickie cechy filozofii Platona. Podobne interpretacje filozofii Platona można znaleźć u innych, zwłaszcza niemieckich badaczy. Por. E. Fink, Metaphisik und Erziehung im Weltverständnis von Platon und Aristoteles, Frankfurt am Main 1970, 54-56; W. Willi, Die orphischen Misterien und der griechischen Geist, „Eranos-Jahrbuch” 11 (1944) 61-105. W. Willi jest przekonany, że udziałem Platona było przeżycie mistyczne typu orfickiego, co miało zdeterminować jego myśl metafizyczna. O orfickich wpływach na Platona pisze też W. Jaeger (Teologia wczesnych filozofów greckich, thum. J. Wocial, Kraków 2007, 149). O misteryjnych i orfickich korzeniach filozofii Platona pisze także niemiecki benedyktyn i filolog klasyczny O. Casel (De philosophorum Graecorum silentio mystico, Berlin 1976, 35-40. G. Reale, włoski autor sztandarowego dzieła Historii filozofii starożytnej, jest przekonany, że bez orfizmu nie da się wytłumaczyć myśli takich filozofów jak Pitagoras, Heraklit, Empedokles czy Platon (tenże, Historia filozofii starożytnej, tłum. E.I. Zieliński, t. 1, Lublin 1993). W Polsce podobne charakterystyki w filozofii greckiej znajdujemy w pracach A. Krokiewicza ( $\mathrm{Za}$ rys filozofii greckiej. Od Talesa do Platona, Warszawa 1971, 7-69; Studia orfickie. Moralność Homera i etyka Hezjoda, Warszawa 2000, 52).

${ }^{11}$ Na temat starożytnych misteriów patrz: U. Bianchi, The Greek Mysteries, Leiden 1976; tenże, La religione greca, Torino 1975; W. Burkert, Starożytne kulty misteryjne, tłum. K. Bielawski, Bydgoszcz 2001; K. Kerényi, Eleusis. Archetypowy obraz matki i córki, tłum. I. Kania, Kraków 2004; tenże, Dionizos, tłum. I. Kania, Warszawa 2008. 
z doświadczaniem boskości (i w ogóle z doświadczaniem czegoś, co można nazwać sacrum). Tak pojmowane wtajemniczenia mają poniekąd charakter zbawczy. Dostąpienie oczyszczenia jest tu równoznaczne z zapewnieniem sobie (już po śmierci) boskości, a więc poniekąd zbawienia, czyli ostatecznego wybawienia z więzów cielesności i zmysłowości.

Tego rodzaju myślenie było bliskie Apulejuszowi i jego duchowemu mistrzowi Platonowi. W dziełach Platona często goszczą wątki i motywy orfickie $^{12}$, a Apulejusz sam był wtajemniczony w misteria Izydy i Ozyrysa, i inne ${ }^{13}$. U obu myślicieli filozofia przedstawia się jako oczyszczenie duszy z wszelkiej zmysłowości i jako droga do boskości, w pełni osiagalnej dopiero po uwolnieniu duszy z cielesnego więzienia, czyli po śmierci ${ }^{14}$. Śmierć zapewnia duszy wejście do wspólnoty z bogami, a zatem tak jak w misteriach, które również obiecywały zjednoczenie $\mathrm{z}$ bóstwem (pełne i ostateczne - również dopiero po śmierci). Można zatem powiedzieć, że filozofia, uprawiana w takiej konwencji, pełni funkcję misteryjną - przetwarza człowieka tak, jak czyni to duchowość misteryjna. Platon, przy całym swoim krytycyzmie wobec rytuałów ${ }^{15}$, nie odrzucał jednak oczyszczeń misteryjnych, tym niemniej podkreślał, że doskonałe oczyszczenie może dać tylko filozofia, a właściwie Prawda, do której ona dąży ${ }^{16}$. Sam nie był wtajemniczony w żadne misteria ${ }^{17}$. Apulejusz był pod tym względem bardziej od niego religijny. Nie tylko poznał wiele kultów misteryjnych, lecz nawet sam osobiście dostąpił licznych wtajemniczeń. Największą rolę odegrały w jego życiu misteria Izydy i Ozyrysa ${ }^{18}$. Opisuje je w ostatniej księdze swoich Metamorfoz. W pierwsze z nich został wtajemniczony w Grecji,

${ }^{12}$ Por. Plato, Leges 715E; 716A; 78C; Res publica 364B-E; Epistulae VII 335a; Symposium 189C - 193D; Phaedo, 62B; Meno 86A-B. Odnośnie wpływów orfickich i w ogóle misteryjnych w filozofii Platona patrz: Albert, Griechische Religion und platonische Philosophie, s. 68 i 84-108 (patrz też polskie wydanie dzieł K. Alberta: Studia o historii filozofii, tłum. B. Baran - J. Marzęcki, Warszawa 2006, 119-129 i 125-148); Krokiewicz, Studia orfickie, s. 7-77; tenże, Zarys filozofii greckiej, s. 7-69; Casel, De philosophorum Graecorum silentio mystico, s. 35-40; Reale, Historia filozofii starozytnej, t. 1, s. 50; R. Mondolfo, Nota sopra la religione greca e I suoi rapport con la filosofia, w: La filosofia dei Greci, ed. E. Zeller - R. Mondolfo, t. 1/1, Firenze 1951, 140-166; A. Louth, The Origins of the Christian Mystical Tradition. From Plato to Denys, Oxford 1983, 1-17 (polskie wydanie: Poczatki mistyki chrześcijańskiej, tłum. H. Bednarek, Kraków 1997, 15-33); Jaeger, Teologia wczesnych filozofów greckich, s. 149. Motywy duchowe, takie jak wtajemniczenia, oczyszczenia, chociaż w kontekstach wychowawczo-politycznych, pojawiają się też w słynnej jego Paideii: (tenże, Paideia. Formowanie się człowieka greckiego, tłum. M. Plezia - H. Bednarek, Warszawa 2001, 760, 1140 i 1041).

${ }^{13}$ Por: Pawłowski, Filozoficzna sylwetka Apulejusza z Madaury, s. 339-352. Zob. też nota 3.

${ }^{14}$ Por. Apuleius, De dogmate Platonis II 20, 249; Plato, Phaedo 81 A-C.

${ }^{15}$ Por. Plato, Res publica II 362B - 366B; 377A - 383C; tenże, Euthyphro 5E - 6A.

${ }^{16}$ Por. tenże, Phaedo 69B-C; 67B-C; 66A-E.

${ }^{17}$ Platon nie mógł być dopuszczony do wtajemniczeń eleuzyńskich, ze względu na ciążącą na jego rodzie pewną sakralną zbrodnię (nieuszanowania, przez jednego z jego przodków, miejsca świętego jako azylu dla podejrzanych o przestępstwo).

${ }^{18}$ Por. Apulejusz, Apologia 55, 56. 
Konchrei nad Zatoką Sarońską, w drugie - w samym Rzymie (doszedł tu nawet do wysokich godności, jak sam sugeruje w zakończeniu jedenastej ksiegi Metamorfoz). Można się domyślać, że religijna duchowość misteryjna, w toku jego zagłębiania się w filozofię Platona, przerodziła się w nim w duchowość filozoficzną (czy filozoficzno-misteryjną), jednak środki, którymi posługiwała się religia, w tym magia, w dalszym ciagu odgrywały w jego życiu swoją rolę ${ }^{19}$. Misteryjne i mistyczne zarazem cechy umysłowości i filozofii Apulejusza wychodzą na jaw również w jego teorii miłości.

1. Apulejuszowa teoria miłości. Duchowe i misteryjne aspekty milości erotycznej. Platonizm był bez wątpienia głównym czynnikiem stymulującym myśl i duchowość Apulejusza z Madaury. W najwyższym stopniu widać to w jego koncepcji miłości, którą wykłada w 13. oraz 14. rozdziale drugiej księgi O Platonie $i$ jego nauce. Pisze tu o niej w kontekście ważnego dla starożytnych filozofów tematu, jakim jest przyjaźń. Miłość jest formą przyjaźnii ${ }^{20}$. Spośród różnych rodzajów przyjaźni i miłości wyróżnia takie, które rodzą się ze wspólnych przyjemności oraz takie, które zawiązują się z konieczności ${ }^{21}$. Miłość krewnych i dzieci jest naturalna, odpowiada naturze. Można o niej w pełni powiedzieć, że jest przyjaźnią w najlepszym tego słowa znaczeniu. Natomiast miłość pospolita, która sprowadza się w istocie do cielesnego pożądaniem, nie zalicza się do przyjaźni. Jest wręcz nieszczęściem dla duszy, namiętnością, która ją opanowuje i zniewala ${ }^{22}$. Apulejusz mówi o trzech rodzajach miłości. Jedną z nich jest miłość boska, bardzo wysublimowana, związana nierozerwalnie z rozumem i cnotą 23 . Druga, przeciwnie - to wyuzdana i pełna rozwiązłości namiętność seksualna, związana z najpodlejszym rodzajem rozkoszy, której pożądać może tylko dusza zwyrodniała ${ }^{24}$. Trzeci rodzaj to miłość pośrednia, mająca w sobie coś z każdej z obu wymienionych rodzajów miłości²5.

${ }^{19}$ Por. tamże 56, 61-64. Apulejusz w swojej Apologii, która przedstawia jego mowę obrończą, którą wygłosił podczas wytyczonego przeciwko niemu procesu o magię, broni się przed zarzutem uprawiania magii, ale mimo woli dał nieraz dowód na to, że najprawdopodobniej jednak wierzy w magię, a w tym w magiczną moc amuletów i zaklęć (tamże 40, 42-43 i 64). O jego sympatii dla magii może świadczyć także to, że największych starożytnych filozofów, takich jak Pitagoras, który był dla niego wielkim autorytetem, zaliczał do magów (tamże 31), i podobnie - Epimenidesa, Orfeusza, Ostanesa i Zoroastra (tamże 26-27). Również w medycynie, którą żywo się interesował, upatrywał pole do zastosowania magii, włącznie z magią zaklęć leczniczych (tamże 40 i 26). Magię uznaje za sztukę królewską, którą nauczyciele wszczepiali synowi króla perskiego (tamże 25; por. Pseudo-Plato, Alkibiades I 121E). Zaciekawienie sztuką magiczną łączy się u niego z zainteresowaniami astrologicznymi. Apulejusz (Florida X i XV) wierzy we wpływ gwiazd i planet na losy ludzkie.

${ }^{20}$ Por. Apuleius, De dogmate Platonis II 13, 238; 14, 240.

${ }^{21}$ Por. tamże II 13, 239.

${ }^{22}$ Por. tamże II 13, 239 - 14, 239.

${ }^{23}$ Por. tamże II 14, 239.

${ }^{24}$ Por. tamże II 14, 240.

${ }^{25}$ Por. tamże. 
Istnieją zatem dwa biegunowo różne rodzaje miłości: miłość idealna, boska, rozwijająca się w duchowej sferze człowieka, i odwołująca się do tego, co stanowi boską cząstkę w człowieku; oraz miłość czysto zmysłowa i ziemska, erotyczna i egoistyczna namiętność, którą opanowany człowiek dąży wyłącznie do zaspokojenia swoich żądz, często nikczemnych a nierzadko zwyrodniałych. Miłość boska ma szlachetne cele. Ogarnięty nią człowiek dąży do etycznego i duchowego ubogacenia siebie samego i ukochanej osoby ${ }^{26}$.

Ziemska miłość wywołana jest przez choroby cielesne i jest właściwością duszy zdegenerowanej ${ }^{27}$. Miłość boska natomiast jest owocem bożego natchnienia, szału Erosa, jednego z czterech boskich szałów, o których pisał Platon w Fajdrosie ${ }^{28}$. Pośredni rodzaj miłości realizuje się pomiędzy tamtymi dwoma i zawiera w sobie wątki zarówno tej boskiej, jak i tej ziemskiej miłości, przy czym te pierwsze wiążą się ściśle z rozumnością człowieka, te drugie $-\mathrm{z}$ jego zmysłowością i cielesnością ${ }^{29}$.

Apulejuszowa koncepcja miłości jest, jak łatwo się domyśleć, wiernym opracowaniem myśli Platona, wyłożonej w Fajdrosie i w Uczcie ${ }^{30}$. Miłość jest jednym z najważniejszych elementów filozofii Platona. Jak uczył Platon, prawdziwa, boska miłość zdolna jest wynieść duszę filozofa do sfery niebiańskiej, tam gdzie króluje idea Piękna, Dobra i Prawdy. Inaczej mówiąc, miłość otwiera oczy duszy na świat nadprzyrodzony i na nadprzyrodzone cele człowieka. Jak bardzo ta nauka była droga Apulejuszowi, świadczy to, że umieścił ją również w Apologii, w swojej mowie obrończej, którą wygłosił przed trybunałem sądowym w $\mathrm{Oe}^{31}$. Przedstawił tu właśnie naukę o dwóch rodzajach miłości - dwóch Wenerach i dwóch Erosach - wiernie odwzorowując obraz namalowany przez Platona w Uczcie:

„Otóż Platon uczy, że są dwie boginie Wenery, a każda sprawuje władzę nad innym rodzajem miłości i nad różnymi wielbicielami. Jedna z nich jest wszystkim znana; ta, gdy ją rozbudzi miłość przyziemna, skłania ku żądzy nie tylko uczucia ludzi, lecz także dzikich zwierząt, z niesamowitą i straszną siłą splatając $\mathrm{w}$ uścisku posłuszne ciała stworzeń porażonych jej potęgą. Druga zaś, niebiańska Wenera, zrodzona ze szlachetnej miłości, troszczy się tylko o ludzi, i to jedynie niektórych spośród nich, nie pobudzając ich niczym, nie podsuwając żadnych przynęt, aby swych wyznawców nakłonić do czynów lubieżnych. Miłość jej nie jest swawolna ani wyuzdana, lecz przeciwnie - prosta i poważna, a pięknem czystości umacnia w swych wielbicielach

${ }^{26}$ Por. tamże II 14, 239-240. Zob. Plato, Phaedrus 256B-E; tenże, Symposium 195E - 197E.

${ }^{27}$ Por. Apuleius, De dogmate Platonis II 14, 240. Zob. Plato, Timaeus 86E.

${ }^{28}$ Por. Apuleius, De dogmate Platonis II 14, 240; Plato, Phaedrus 244A - 245B; 265B. Te cztery boskie szały to: mistyczny szał dionizyjski, prorocze natchnienie apollińskie, szał poetycki od Muz i szał miłosny, który pochodzi od Erosa i Afrodyty.

${ }^{29}$ Por. Apuleius, De dogmate Platonis II 14, 240.

${ }^{30}$ Por. Plato, Symposium 210A - 212A; także: 195C - 196D; tenże, Phaedrus 250D - 251B.

${ }^{31}$ Por. Apuleius, Apologia 12. 
umiłowanie cnoty; jeśli nawet czasem zwróci uwagę na urok ciała, to zarazem oddala wszelkie pragnienie skalania go; bo tylko to w kształtach ciała godne jest uwielbienia, co przypomina boskim duszom o owym pięknie, jakie w postaci czystej i prawdziwej widziały kiedyś wśród bogów. Dlatego, choć nawet Afraniusz pozostawił pełne wdzięku powiedzenie: ,mądry będzie kochał, pozostali będą pożądać”, to Emilianie, lub jeśli w ogóle jesteś zdolny to zrozumieć, mądry nie tyle kocha, co przypomina sobie"32.

\section{Duchowe aspekty baśni o Erosie i Psyche. Miłość jako wtajemnicze-} nie w boskość. Baśń o Erosie i Psyche budzi i różne skojarzenia, w zależności od tego, które jej wątki weźmie się pod uwagę, a zapewne w zależności jeszcze od nastawienia czy nawet profesji czytelnika. Psycholog będzie w niej szukał potwierdzenia swoich teorii na temat psychiki kobiety, mężczyzny czy jeszcze czegoś. Seksuolog czy antropolog będzie szukał elementów, które będą poświadczać taką czy inną, uznawaną przezeń, teorię. Pozostali czytelnicy mogą w niej odkryć jeszcze inne aspekty, jak w każdej baśni. Baśnie rzeczywiście obnażają różne aspekty i różne strony ludzkiej natury i rozmaite elementy związków międzyludzkich. Także w baśni Apulejusza można je dostrzec. Świadomi tych różnych możliwości metodologicznych, spróbujmy spojrzeć na tę baśń wyłącznie poprzez pryzmat filozofii Apulejusza ${ }^{33}$.

Wypada na początku przypomnieć, że filozofowie platońscy, należący do tego nurtu filozofii, w którym tworzył Apulejusz, często wykorzystywali różnej postaci mity, baśnie i różnorakie alegorie, by przy ich pomocy coś wyrazić. Przykład dał sam Platon, który w sposób niemal naturalny korzystał z tej formy przekazu. Przypomnijmy też, że przekaz mityczny i alegoryczny nie ograniczał się do komunikacji tylko takiego czy innego przesłania, zwykle dodajmy - łatwego do rozszyfrowania. Było w nim coś jeszcze. Otóż mit, czy jakiś obraz alegoryczny, swoją ekspresją oddziaływał na człowieka, na jego uczucia, emocje, coś w nim wyzwalał, jakieś niepokoje, nadzieje, a czasem coś więcej - może autentyczne przeżycia egzystencjalne (egzystencjalne doświadczenie rzeczywistości, o której mówi przesłanie tego mitu), a przynajmniej

${ }^{32}$ Tamże 12, ed. P. Vallette, w: Apulée, Apologie, Florides, Paris 1924, 15, tłum. J. Sękowski: Apulejusz, Apologia, czyli w obronie własnej ksiega o magii, Warszawa 1975, 27. Por. Plato, Symposium 180D - 181D; 185C.

${ }^{33} \mathrm{Na}$ temat baśni $O$ Erosie i Psyche Apulejusza i jej różnych interpretacjach zob. G. Schaller, De fabula apuleiana quae est de Psyche et Cupidine, Lipsiae 1901; R. Reitzenstein, Das Märchen von Amor und Psyche bei Apuleius, Leipzig - Berlin 1912; U. De Maria, La favola di Amore e Psiche nella letteratura e nell'arte italiana, Bologna 1899; S. Costanza, La fortuna di L. Apuleio nell'eta di mezzo, Palermo 1937; E. Paratore, La novella in Apuleio, Messina 1942; R. Merkelbach, Roman und Mysterium in der Antike, München 1962; J.O. Swahn, The Tale of Cupid and Psyche, Lund 1955; T. Mantenero, Amore e Psiche. Struttura di una fiaba di magia, Genova 1973; F.E. Hoevels, Märchen und Magie in den Metamorphosen des Apuleius von Madaura, Amsterdam 1979; E.J. Kenney, Cupid and Psyche, Cambridge 1990; C Moreschini, Il mito di Amore e Psiche in Apuleio, Napoli 1994. 
jakieś przeczucia czy intuicje (dotyczące rzeczywistości, o której mówi dane przesłanie). Innymi słowy, komunikacyjna funkcja filozoficznego mitu czy alegorii filozoficznej nie ogranicza się do samego przesłania. Jest w niej jeszcze bezpośrednie oddziaływanie na człowieka, na jego ukrytą, wewnętrzną wrażliwość duchową i moralną, a więc wrażliwość na to, co inaczej jest nieuchwytne, np. wrażliwość na piękno moralne i duchowe. Przykładem są tu mity i alegorie z Platońskich dialogów, a także te, których używali platonicy z późniejszych czasów, i które znajdujemy w ich dziełach. Najlepszym przykładem jest tu twórczość Plutarcha, ale Apulejusz i inni filozofowie średniego platonizmu niewiele mu ustępują. Niektórzy z nich porównywali twórczość filozofa do wyroczni. Filozof miał objawiać boską mądrość, ale by to mógł czynić, sam wpierw musiał jej doświadczyć. Z drugiej strony, boska mądrość $\mathrm{z}$ natury swojej nie daje się wyrazić w ludzkich słowach. Te zresztą nie byłyby zdolne wskrzesić w duszy tego, o co chodziło, czyli duchowej wrażliwości. Filozof przeto musiał korzystać z mitycznej i alegorycznej formy przekazu. Mit niósł przesłanie (czyli jakąś myśl), ale także wtajemniczał w rzeczywistość, o której mówiło owo przesłanie, a przynajmniej mógł tak oddziaływać, jeśli padł na podatny grunt. Pod tym względem mit filozoficzny przypominał dawne mity misteryjne, które ukazywały wtajemniczanym boskość (a więc nadprzyrodzoność), w tym w boskość duszy ludzkiej. Demeter szukającą swojej córki, Kory, w micie eleuzyńskim, można pojmować jako swego rodzaju alegorię człowieka, który trudząc się z samym sobą i wtajemniczając w końcu w jej misteria, usiłował rozszyfrować tajemnicę swoich najintymniejszych, miłosnych tęsknot, a przez nie odkrywał najtajniejszą tajemnicę własnej natury, a więc $\mathrm{w}$ istocie poszukiwał samego siebie i znajdował (w duchowym doświadczeniu boskości), tak jak Demeter, która odnajdując córkę, odnajdywała samą siebie ${ }^{34}$. I tu tym, co prowadzi człowieka (jak samą Demeter) do pełni boskości, jest miłość. Podobnie w misteriach orfickich wtajemniczani odkrywali i przeżywali dionizyjskość własnej duszy i swoją jedność z Dionizosem, $\mathrm{z}$ bogiem, a tym samym swoje nadprzyrodzone korzenie i powołanie.

Mity misteryjne można traktować jako swego rodzaju alegorię poszukującego siebie człowieka - alegorię człowieka, który chce odkryć i zrozumieć samego siebie i swoje tęsknoty za szczęściem i boskością. Motorem owych wtajemniczeń, a zarazem duchowej przemiany wtajemniczanego człowieka (związanej z odsłonięciem jego wewnętrznej natury) jest zawsze miłość. To miłość zmusiła Demeter do wędrówki za Kora. To miłość karze wszystkim tęskniącym za czymś tajemnym, a odczuwanym jako coś, co kiedyś było ich, a co utracili (kiedyś tam, nie wiadomo kiedy), szukać tego czegoś. I znajdują

${ }^{34}$ Mit o Demeter i Korze uzmysławia, że do pełni boskości prowadzi miłość (tak jak samą Demeter). Miłość odkrywa w człowieku to, co boskie. Dzięki miłości człowiek wprowadza w swoje życie wymiar nadprzyrodzony. Najprościej rzecz ujmując, miłość pozwala odczuć człowiekowi, że jest w nim coś nadprzyrodzonego. Pozwala mu ujrzeć własne życie i cały świat w perspektywie nadprzyrodzonej. 
to, jeśli tylko odnajdą w sobie miłość, uświadamiając dzięki temu, że to właśnie miłość jest tym, czego szukali. Doświadczając tej miłości, doświadczają najprawdziwszej boskości. Zarazem uzmysławiają sobie starą prawdę, że tyle jest boga w nich (i w świecie), ile jest w nich miłości. Widać zatem, że to miłość stanowi, jeśli tak można powiedzieć, największą tajemnicę ludzkiej natury i ludzkiego życia, a zarazem powołanie.

Pamiętamy, że Apulejusz był wtajemniczony w różne misteria. Zatrzymajmy się na chwilę na tych ostatnich, na wtajemniczeniach misteryjnych. Sednem tych wtajemniczeń było duchowe doświadczenie boskości, najogólniej mówiąc, przeżycie nadprzyrodzoności istniejącej gdzieś w świecie, czy raczej poza „tym światem”, oraz w samym człowieku, choć poza jego widzialną cielesnością. Wtajemniczany dotykał nadprzyrodzoności i uświadamiał sobie, że nosi w sobie cząstkę nadprzyrodzoności (boskości), ukrytą pod grubą powłoką materialnego ciała, którą musi ożywić i wyzwolić. Uzmysławiał sobie zarazem, iż drogą do tego wyzwolenia jest zawsze miłość.

Można powiedzieć, że wtajemniczenia misteryjne objawiają istotę miłości. Miłość jest tym, co kieruje człowieka na świat pozamaterialny i pozazmysłowy, a jednocześnie budzi w nim samym i wyzwala coś, co jest niematerialne i niezmysłowe (choć może objawiać się zmysłowo, czy raczej jakby zmysłowo, tak jak w przypadku niezwykłego piękna Psyche). Miłość, jak pokazuje baśń o Erosie i Psyche, ma w sobie moc, dzięki której zdolna jest pokonać wszelkie przeszkody, i w ogóle wszelkie zło, zwłaszcza to, które rodzą ludzkie namiętności i żądze. Miłość ma w sobie coś boskiego, i współgra z tą miłością, która jest prawem natury. W baśni ujawnia to się w tym, że Psyche w pracach pomagają różne stworzenia i siły natury.

Jak powiedziano wyżej, także w filozofii Apulejusza miłość ma wymiar boski. Zaczyna się zawsze od boskiego natchnienia i w ostateczności prowadzi do boga. Oczywiście dotyczy to tylko tej „prawdziwej” miłości. Miłość czysto zmysłowa, którą Apulejusz, za Platonem, nazywał „,zwierzęcą”, w ogóle nie zasługuje, jego zdaniem, na miano miłości. Jest zwykłą żądzą, w której nie ma nic $\mathrm{z}$ delikatnej i czułej namiętności cechującej prawdziwą miłość, a wprost przeciwnie jest wręcz zła i odrażająca. Rodzi się ona bez ingerencji Erosa i miewa zwykle katastrofalne dla ludzi skutki. Związki oparte na takiej, pozbawionej boskiego natchnienia, żądzy są równie złe i odrażające jak ona sama $^{35}$. Tak właśnie wyglądały owe związki między ludźmi w świecie, gdy zabrakło w nim Erosa, kiedy ten leczył swoje rany w domu swojej matki. Tak to przedstawia w baśni mewa Afrodycie. Natomiast miłość, którą zsyła Eros, jest zawsze czuła i delikatna. I taka też jest namiętność erotyczna z nią związana, wolna od jakiejkolwiek przemocy i zła, bo obecny w niej jest sam bóg, który wraz z natchnieniem, czarem, który zsyła na ludzi, udziela im samego siebie.

Prawdziwa miłość ma zawsze coś boskiego w sobie, jest delikatna i czuła, jak sam bóg. I stąd też pochodzi jej siła. Dlatego zdolna jest ona pokonać

\footnotetext{
${ }^{35}$ Por. Apuleius, De dogmate Platonis II 14, 239. Zob. tenże, Metamorphoses V 28.
} 
wszystko, nawet śmierć. Pierwszym przykładem (archetypem) takiej miłości była miłość Orfeusza, który kochał Eurydykę nawet wtedy, gdy nie mógł jej wyprowadzić z Hadesu (skutkiem ciekawości, i podobnie było z Psyche w baśni Apulejusza). Co więcej kochał ją jeszcze bardziej i jeszcze czyściej, bo duchowo. Miłość wzniosła go na wyżyny boskości i uczyniła bogiem, podobnie jak Eurydykę. Według pewnego mitu, Orfeusz i Eurydyka zaślubili się ponownie, ale już jako bogowie. Miłość wyniosła ich oboje do boskości, ale tylko dlatego, że sama była boska. Po czym można było poznać, że była boska? Otóż po tym, że przezwyciężyła i przeżyła wszystko, nawet śmierć. I jeszcze po czymś. Otóż taka miłość zgrywa się zawsze, rezonuje z tą miłością, która jest prawem natury. Widać to było po tym, że gdy Orfeusz grał czy śpiewał, słuchały go wszystkie stworzenia, cała natura wsłuchiwała się w jego pieśn, a właściwie - w jego miłość, którą wyśpiewał w tej pieśni, a była to ta sama miłość, którą żyje cała natura. Powiedzmy jeszcze dobitniej - miłość jest bogiem, tym prawdziwym, nie tym, którego czci się na ołtarzach, i który żądny jest ludzkich ofiar, a często łaknie krwi. Powtórzmy jeszcze raz: miłość jest bogiem, jest jedynym bogiem. Reszta bogów - to tylko fantomy, cienie ludzkich żądz i namiętności.

Baśń o Erosie i Psyche równie wyraźnie to pokazuje. Pokazuje w pierwszym rzędzie, że miłość jest bogiem (Eros jest bogiem). Uwidacznia zarazem, że taka boska miłość jest zawsze piękna i wyzwala w człowieku ukryte piękno, ale piękno inne, niż to zwyczajne, z jakim ludzie się zwykle spotykają. Wyzwala piękno, jakim emanowała właśnie Psyche z baśni Apulejusza, piękno - jak jest wyraźnie powiedziane w baśni - niewyrażalne ${ }^{36}$. Psyche była bardzo urodziwa. Jednak jej piękna żaden człowiek nie był w stanie ani uchwycić w słowach, ani wyrazić, choć go doświadczał. Doświadczał go niby

${ }^{36}$ To sugeruje, że mamy do czynienia z czymś niezwykłym, co przekracza zwykłe baśnie niewyrażalność jest cechą boskości. Takie określenie urody na pozór zwykłej dziewczyny może sugerować, że mamy do czynienia z pięknem innej natury, aniżeli piękno ludzkie. Przeczuwamy, że chodzi tu o piękno natury duchowej, które choć ujawnia się poprzez fizyczną urodę i wdzięk, jest jednak innej natury, bo w przeciwnym przypadku dałoby się wyrazić, w taki czy w inny sposób, w słowach. Poza tym, budziłoby ono uczucia natury zmysłowej, a nic takiego się nie działo. Zamiast tego, uroda Psyche budziła w ludziach nabożną cześć. Oglądanie piękna Psyche jest, jak można się domyślać, przeżyciem nie tylko estetycznym, lecz także i przede wszystkim duchowym. Poruszało w ludziach nie tylko wrażliwość estetyczną, lecz przede wszystkim duchową, a więc czułość na to, co nadprzyrodzone. Ludzie dostrzegali w niej coś boskiego. Fizyczna uroda Psyche jest przejawem jej piękna duchowego i moralnego, ale jednak potencjalnego (czyli jeszcze nie w pełni rozwiniętego), które powinna w sobie zrealizować czy zaktualizować, a drogą do tego jest miłość „racjonalna”, która nie ulega podszeptom namiętności czy tylko ciekawości, i nie daje się zwieść. Psyche przyjmuje składane jej hołdy. To znak, że jej wrażliwość duchowa (i boskość) jeszcze nie jest w pełni rozwinięta. Boskość, czyli pełne, dojrzałe człowieczeństwo ciagle jest jej zadaniem do spełnienia. I stąd jej późniejsze uleganie zgubnej ciekawości, a nawet zmysłowej namiętności erotycznej (na widok Kupidyna), choć usprawiedliwia ją to, że sam boski Eros też uległ wcześniej żądzy, co nie jest bez znaczenia. Zdaje się bowiem świadczyć, że i on jest jeszcze niedojrzały w swej boskości i również musi jeszcze ową boskość w sobie rozwijać. 
za pośrednictwem zmysłów, ale jednak nie było to tylko doznanie zmysłowe. Przypomnijmy, że niewyrażalność jest cecha, która znamionuje boskość. Już to sugeruje, że w pięknie Psyche jest coś niezwykłego, coś, co nie podlega kanonom urody ziemskiej. Jej nadzwyczajna uroda, piękno, nie budzi zmysłów, budzi coś, co jest poza tymi zmysłami, i wyzwala uczucia zupełnie innej natury, niż te, które zdolne są wzbudzić jakiekolwiek wartości zmysłowe. Ludzie składali Psyche wyrazy uwielbienia, i padali przed nią na kolana, bo budziła w nich to, co w nich samych było najszlachetniejsze i najwznioślejsze. Oglądając jej piękno (niby fizyczne, a w istocie chyba jednak nie fizyczne, lecz duchowe) doświadczali w tym (niby fizycznym) pięknie tajemnicy piękna ludzkiej natury - prawdziwej ludzkiej natury, nie tej materialnej i zmysłowej. Gdyby nadzwyczajna uroda Psyche była tylko wyrazem materialnej i zmysłowej natury, to budziłaby zmysłowe pożądanie, a nie budziła.

3. Historia Psyche jako parabola dziejów ludzkiej duszy. Historia Psyche, widziana w perspektywie filozofii Apulejusza, może być pojmowana jako swego rodzaju parabola dziejów ludzkiej duszy, i to nie tylko dlatego, że tak mogłoby wskazywać imię Psyche (skądinąd wiadomo, iż było to dość pospolite imię w Grecji, podobnie jak imię Erosa).

Od początku widać, że w Psyche jest coś niezwykłego, nieziemskiego. Jest $\mathrm{w}$ niej coś prawdziwie boskiego, co uwidacznia się wprawdzie poprzez zmysłowe piękno, należy jednak do innego świata, nieziemskiego, nadprzyrodzonego, a więc boskiego. Niebawem okaże się, że owa boskość Psyche nie jest jednak w pełni zaktualizowana. Wymaga niejako wypełnienia. Psyche reprezentuje szlachetny, duchowy aspekt ludzkiej natury, który jednak nie jest jeszcze w pełni ukształtowany i zrealizowany.

Najkrócej przesłanie baśni można wyrazić następująco: Psyche reprezentuje boski, nadprzyrodzony aspekt ludzkiej natury. Jej historia to w istocie rzeczy alegoria życia człowieka, który poszukuje swojego spełnienia, a zarazem usiłuje jakoś zgłębić tajemnicę swojej ludzkiej natury, czując, że jedyną drogą, która może dowieść go do tego celu, jest miłość.

Jak wiadomo tego rodzaju mity i baśnie są wielowarstwowe i można je rozmaicie odczytywać. Różne jej postaci mogą wyrażać tylko różne warstwy i aspekty tej samej natury. Psyche bez wattpienia wyraża to, co w człowieku najszlachetniejsze. Uosabia jego tęsknoty do piękna, wieczności, boskości i nadprzyrodzoności. Ale nie tylko ona reprezentuje tu człowieka i jego złożoną i po trosze okaleczoną naturę. W baśni występują jeszcze dwie siostry Psyche, które również są bardzo urodziwe, ale urodą właściwą dla czysto zmysłowej natury. Można się nawet domyślać, iż ta uroda jest przejawem ich bujnej, zmysłowej natury, skłonnej do egoizmu, zawiści i, jak się okazało, do wszelkiej zbrodni. Na planie antropologii platońskiej, reprezentują one te sfery duszy ludzkiej i ludzkiej natury, które wiążą człowieka ze światem zwierzęcym. Wkrótce te cechy objawią się w najgorszy sposób, by w końcu zawieść obie 
siostry w przepaść. Psyche swoją wędrówkę w poszukiwaniu Erosa będzie musiała zacząć od ostatecznej rozprawy z siostrami. Będzie musiała sprawić, żeby ostatecznie zniknęły z jej życia. W ten sposób oczyści się ze zmysłowości, co jest koniecznym warunkiem tego, by jej miłość mogła wspiąć się na poziom czysto duchowy.

Sama Psyche również jest jeszcze duchowo niedoskonała, co przejawia się głównie w jej niepohamowanej ciekawości i łatwowierności wobec sióstr. Jednym słowem, Psyche jest jeszcze niedojrzała duchowo. Dojrzałość wymaga hartu, a ten wypracowuje się w trudzie. Ciekawość doprowadzi ją w końcu do dramatycznego stanu, który ujawnił, że była jednak jeszcze pogrążona w zmysłowości. Jak się okaże, było to chyba jednak, w sumie, potrzebne, bo bez tego Psyche nie stałaby się tym, kim się stała, a w każdym razie nie osiągnęłaby pełnej dojrzałości w swej miłości.

Nietrudno się domyśleć, że wiele wątków z baśni ma znaczenie wyłącznie fabularne i zapewne nie ma ukrytych sensów. Te jednak, które wiążą się z samą Psyche bezpośrednio, są, jak się wydaje, ważne. I tak wypada je potraktować. Przyjrzyjmy się pod tym kontem historii Psyche i Erosa.

Do utraty męża doprowadza przede wszystkim Psyche jej ciekawość. Nie chce się zadowolić samą świadomością tajemnicy natury swego męża (tajemnica jego boskości). Chce ją rozszyfrować, ale bardzo prostymi środkami, i do tego jeszcze nakłoniona przez swe zmysłowe, zawistne siostry. Widać, że jej miłość nie jest jeszcze dojrzała, a zrozumienie natury człowieka i ludzkiej egzystencji (w tym, co naprawdę jest $\mathrm{w}$ niej istotne) przychodzi wraz z dojrzała miłością. Wraz z dojrzałą miłością przychodzi też zrozumienie sensu ludzkiej egzystencji i związanego z tym powołania do boskości, której istotę stanowi miłość. Dojrzałość jest jednak efektem żmudnego wysiłku, przede wszystkim duchowego i moralnego. Przede wszystkim jest ona owocem dojrzałej miłości. Ta zaś jest wtedy dojrzała, gdy łączy się z wrażliwością duchową i moralną. Fundamentem dojrzałej miłości jest zawsze wrażliwość duchowa i moralna, która sprawia, że człowiek nie ulega żadnym fałszywym wartościom i nie daje się im omamić. Kieruje się on miłością, która (jak pokazuje baśń) zdolna jest przezwyciężyć wszystkie przeszkody, również w nim samym, i czyni go w ten sposób prawdziwie wolnym. Okazuje się tym samym, że źródłem prawdziwej wolności jest miłość. Człowiek kierujący się miłością jest wolny, a w każdym razie nie jest niewolnikiem żadnych żądz i ,ziemskich" ambicji.

Domyślamy się, że Eros, przy całej polimorficzności tej postaci w baśni Apulejusza również reprezentuje jakiś aspekt ludzkiej natury. Można powiedzieć, że wyraża jej najgłębszą tajemnicę, którą jest boskość, ale boskość pojęta jako zadanie do zrealizowania, a nie do oglądania i to ciekawskimi oczyma ciała. By poznać najgłębszą tajemnicę ludzkiej natury i ludzkiej egzystencji nie wystarczy zwykła ciekawość. Tajemnica ta bowiem otwiera się tylko przed zakochanym, ale zakochanym prawdziwie. Kto kocha nie pyta o sens ludzkiej egzystencji, bo odczuwa go swym sercem. Przypomnijmy: kto kocha, wiąże się 
z samym bogiem, który jest tą miłością. Dostępuje tym samym swego rodzaju wtajemniczenia w boskość, które rozwiązuje największą tajemnicę ludzkiego życia. Baśń sugeruje dość wyraźnie, że prawdziwe wtajemniczenie w boskość może sprawić tylko miłość. I Psyche to oczywiście osiagnie. Jej miłość dojrzeje. W jej historii, zwłaszcza w jej zmaganiach z zazdrosną i urażoną matką Erosa, ale również z siostrami, odbija się proces jej duchowego dojrzewania.

Afrodyta to znowu, jak Eros, postać polimorficzna i wieloaspektowa, ale dla zrozumienia samej Psyche nie najważniejsza. Można rzec, że uosabia namiętność erotyczną, z jej ambicjami i niebezpieczeństwami, które należy przezwyciężyć i pokonać.

Warto zwrócić uwagę na to, jak dojrzewała miłość Psyche i ona sama. Widać to zwłaszcza, jak powiedziano, w jej zmaganiach z siostrami i z Wenerą. Najciekawsze i znaczące wydaje się w tym to, że Psyche pomagają różne siły natury (które w baśni uosabiają mrówki, wieża, trzcina i orzeł). Ratują ją z chwilowego załamania i pomagają w wykonaniu zadań, które bez ich pomocy nie mogłyby być wykonane. Domyślamy się, że reprezentują one moce natury rządzącej się prawem miłości. Można rzec, że miłość Psyche rezonuje z tą miłością, która jest powszechnym prawem natury. Za tym kryje się intuicja, że miłość jest naturalnym stanem ludzkiej duszy. W miłości odnajduje ona swoje spełnienie, także w sensie nadprzyrodzonym. Miłość uruchamia duchowe energie w człowieku, i jego samego prowadzi do boskości i do wieczności, do której w swej istocie jest powołany.

Historia Psyche i jej zmagania z Afrodytą to alegoria dojrzewania jej miłości. Początek tej drogi, która wiedzie do tej dojrzałości, stanowi radykalne odrzucenie wszelkich form mrocznych żądz i namiętności (w baśni symbolizują je przede wszystkim siostry Psyche, ale również Afrodyta). Dalsze etapy to wznoszenie się tej miłości na poziom duchowy.

\author{
THE TALE OF CUPID AND PSYCHE \\ BY LUCIUS APULEIUS MADAURENSIS. \\ THE SPIRITUAL ASPECTS OF THE TALE
}

\title{
(Summary)
}

This work will discuss the eponymous tale of „Cupid and Psyche”, originally written as a part of Lucius Apuleius Madaurensis' „Metamorphoses”. The tale's main thread, the motif of Psyche making an effort to reclaim Cupid's lost affection, is depicted through the means of mysteriosophic context of Apuleius' philosophy, as well as his theory on love. The work will draw upon the characteristic motifs of the ancient sacred mysteries, thus suggesting that the story of Psyche's trials and tribulations is somewhat an allegory of the spiritual development of man, who searches for love to find the meaning of his life and the fulfillment of his spiritual yearning for the eternal and the divine. 
Key words: Apuleius, Cupid and Psyche, Metamorphoses, ancient mysteries, mysteriosophy, Middle Platonism.

Słowa kluczowe: Apulejusz, Eros i Psyche, Metamorfozy, starożytne misteria, misteriozofia, średni platonizm.

\section{BIBLIOGRAFIA}

\section{Źródła}

Apuleius, Apologia, ed. P. Vallette, w: Apulée, Apologie. Florides, Paris 1924, 1-123, thum. J. Sękowski: Apulejusz, Apologia, czyli w obronie własnej księga o magii, Warszawa 1975.

Apuleius, De dogmate Platonis, ed. P. Thomas, w: Apulei Platonici Madaurensis Opera quae supersunt, vol. 3: Libri de philosophia, Leipzig 1908, 82-134.

ApuleIus, Metamorphoses, ed. R. Helm: Apulei Platonici Madaurensis Opera Quae Supersunt, vol. 1: Metamorphoseon libri XI, Lipsiae 1955, tłum. E. Jędrkiewicz: Apulejusz, Metamorfozy albo złoty osiot, Warszawa 1976.

Plato, Opera, vol. 1-5, ed. J. Burnet, Scriptorum Classicorum Bibliotheca Oxoniensis, Oxonii 1900-1907.

\section{Opracowania}

Barra G. - Pannuti U., Esperienza filosofica e religiosa di Apuleio, „Annali della Facolta di lettere e Filosofia dell' Universita di Napoli” 10 (1962-1963) 81-141.

Berthold F., Die religiösen Anschauungen des Apuleius, Bonn 1925.

Bertozzi A., La posizione filosofica di Apuleio, „Sophia” 17 (1949) 238-245.

De Maria U., La favola di Amore e Psiche nella letteratura e nell'arte italiana, Bologna 1899.

Hoevels F.E., Märchen und Magie in den Metamorphosen des Apuleius von Madaura, Amsterdam 1979.

Kenney E.J., Cupid and Psyche, Cambridge 1990.

Mantenero T., Amore e Psiche. Struttura di una fiaba di magia, Genova 1973.

Mantenero T., Enciclopedismo e misteriosofia in Apuleio, „Quaderni del Teatro Stabile di Torino" 20 (1970) 63-111.

Merkelbach R., Roman und Mysterium in der Antike, München 1962.

Moreschini C., Apuleio e il platonismo, Firenze 1978.

Moreschini C., Il mito di Amore e Psiche in Apuleio, Napoli 1994.

Paratore E., La novella in Apuleio, Messina 1942.

Reitzenstein R., Das Märchen von Amor und Psyche bei Apuleius, Leipzig - Berlin 1912.

Schaller G., De fabula apuleiana quae est de Psyche et Cupidine, Lipsiae 1901.

SwaHn J.O., The Tale of Cupid and Psyche, Lund 1955. 